\title{
Aspects of forecasting calculation of investment mechanism on the use of forest resources in context leadership of border territories in Ukraine
}

Oksana Drebot, Institute of Agroecology and Environmental Management of the National Academy of Agrarian Sciences of Ukraine, 12 Metrological Str., Kyiv, 03143, Ukraine, drebot_oksana@ukr.net, ORCID ID: https://orcid.org/0000-0003-2681-1074

Andriy Gadzalo, Institute of agriculture of Carpathian region of the National Academy of Agrarian Sciences of Ukraine, ahadzalo@ukr.net, ORCID ID: https://orcid.org/0000-0002-0675-2831

Mariya Vysochanska , Institute of Agroecology and Environmental Management of the National Academy of Agrarian Sciences of Ukraine, 12 Metrological Str., Kyiv, 03143, Ukraine, mariya_vysochanska@ukr.net, ORCID ID: https://orcid.org/0000-0003-2116-9991

\begin{abstract}
The analysis of the main indicators of the forest resource potential of the border regions of Ukraine as of 2017, as well as the area of forest reproduction by sowing and planting forests in the context leadership border regions of Ukraine. The relationship of capital investment to the rational use of natural resources, UAH million, the area of forest reproduction, by region, thousand hectares, is analyzed. and the environmental stability factor for the period 1990-2017. On the basis of the correlation analysis it was proved that a sufficient level of influence of the volume of foreign investments on the environmental tax, the costs of enterprises for the protection and rational use of natural resources, the amount of emissions per 1 person indicates a moderate direct relationship between these environmental and economic factors. The algorithm of stages of carrying out of the multifactor regression model, which provides definition and selection of ecological and economic indicators, is developed. After all, the objectives and main objectives of the investment mechanism are to meet certain conditions for the prospect of development of the context leadership border regions. And the criteria of the mechanism are intended to ensure the realization of strategic and tactical goals and levers applied by the bodies of regional government and local self-government within their powers, with the aim of forcing in this territory the conditions for expanded reproduction and ensuring ecological and economic development.
\end{abstract}

Keywords: balanced environmental management, coefficient of ecological stability, ecological and economic security, ecological stability factor, economic mechanism, environmental protection, leadership aspects.

Received: 08.12.2020 $\quad$ Accepted: 15.01.2021 $\quad$ Published: 06.02.2021

\section{Introduction}

It is worth noting the various theoretical aspects regarding the prediction of the economic mechanism of natural resources use, which have become a cornerstone of scientific research. It is determined that the organizational and economic mechanism of ecologically balanced forestry management implies the effective functioning of the investment mechanism, which is a set of measures to influence the ecological and economic structure of the industry (Furdychko 2017, Wadim Strielkowski, Evgeny Lisin, Inna Gryshova, 2016).

According to (Wadim Strielkowski, Gryshova I.Yu, 2018)), the underdevelopment of the investment mechanism in our country and the lack of a balanced systematic approach that have caused the environmental imperative to be neglected by nature users. The lack of a consolidated civil society has led to frequent violations of the institute of ownership of natural resources. That is why, due to the improvement of the institutional and investment paradigm of the relationship between society and nature, the issue of the investment mechanism for attracting foreign or domestic investments in the environmental sphere should be resolved. Concerning the rational use of forest resources and their involvement in the financial management of forestry (Gryshova, I.; Shabatura, T.; Girdzijauskas, S.; Streimikiene, D.; Ciegis, R.; Griesiene, I.,2019), over-exploitation of forest resources in the past has led to an aggravation of the ecological and economic situation in Ukraine: the area of forests has decreased by more than a millennium three times, anthropogenic transformation of forest ecosystems occurred, their natural productivity decreased, biological diversity was depleted, forest reserves were depleted, ecological functions were degraded forest plantations. Due to lack of necessary funds, the rates of 
reforestation and afforestation remain low, no measures are being taken to intensify the cultivation of the forest, the disproportion between the forest resources base and the economic potential of the woodprocessing, pulp and paper industry, construction, other traditions of the economy is increased (Shershun 2013, Antonenko 2001). According to (Gryshova et al. 2020), the modern paradigm of sustainable development involves the development of new solutions to ensure sustainable development of the manufacturing sector, the creation and adoption of technological investment and innovation processes. (Azer Dilanchiev, Gryshova Inna, Rogach Svetlana, Diachenko Oleksii, Batrakova Tetyana, Shabatura Tatyana, 2019)

Paying attention to the achievements of leading scientists it should be noted that there is a shortage of comprehensive research in this field, to date no methodological approach on rational use of forest resources due to their involvement in the implementation of investment projects.

\section{Materials and methods of research}

To date, there is no methodological basis for research on balancing the use of natural resources in border areas and methods for their study (Andel 2009.) therefore, in this study, it is appropriate to analyze the rational use of forest resources, as well as not only the environmental aspect of the environment, but also the economic one, which implies an investment mechanism aimed at improving and attracting and developing the border regions, which will allow to trace the main stages and trends of development. border areas of Ukraine, as well as to identify the impact of environmental factors and make certain environmentally sound organizational and management decisions to prevent and the effective use of natural resources, including forest resources. The methodological basis of the study is general theoretical methods of scientific knowledge, fundamental provisions and principles of economics of nature management in the border areas. The researches were conducted by using dialectical method of knowledge of the effect of economic laws and systematic approach to the study of ecological and economic phenomena; mathematical-statistical method was used to process information on the basis of correlation-regression method for determining the influence of environmental and economic factors on the border areas; programmatic target method for development of strategic directions of estimation of investment mechanism of forest resources and optimal use of investment mechanism for restoration and use of forest resources; abstract-logical method was used for theoretical and methodological generalizations and formulations of conclusions.

\section{Results and discussions}

Forest as a natural resource is one of the most important human resources, which in the formation of the environment of human existence is not replaceable, unlimited and multifaceted environmental, economic and social functions. State-owned forest resources are one of the most important factors of production, along with other factors - labor and capital. The nature of the use of forest resources depends on the level of socio-economic development of the society, as well as the state of the environment. (Dr. Tetiana Tielkiniena, Gryshova Inna, Shabatura Tatyana, Nehodenko Viktoriia, Didur Hanna, Shevchenko Alisa, 2020)

According to the State Forest Account (State Statistics Service of Ukraine 2018), as of 2017, the area forest land in Ukraine is $603,7 \mathrm{mln}$. ha, including the forested land - 9665,6 ha. Thus, the forest cover (the share of land covered with forest vegetation in the total area of the country's territory) is 15,900 ha. (Table 1). As this figure is slightly lower than in many European countries and is $15.9 \%$ (Fig. 1).

Table 1. Key indicators of the forest resource potential of the border regions of Ukraine as of 2017.

\begin{tabular}{|c|c|c|c|c|c|}
\hline \multirow[b]{2}{*}{ Regions } & \multirow[b]{2}{*}{ Afforestation, \% } & \multicolumn{2}{|c|}{$\begin{array}{l}\text { Forest lands, } \\
\text { thousand ha }\end{array}$} & \multirow{2}{*}{$\begin{array}{lr}\begin{array}{l}\text { Volume } \\
\text { products, }\end{array} \\
\text { works } \\
\text { services } \\
\text { forestry, } \\
\text { thousand } \\
\end{array}$} & \multirow{2}{*}{$\begin{array}{l}\text { Supply of } \\
\text { liquid wood - } \\
\text { total, thousand } \\
\mathrm{m}^{3}\end{array}$} \\
\hline & & Total & $\begin{array}{l}\text { Land } \\
\text { covered }\end{array}$ & & \\
\hline Vinnytsia & 13,1 & 26.5 & \begin{tabular}{|l|}
361.3 \\
\end{tabular} & 678.9 & 639.5 \\
\hline Volyn & 31.0 & 20.2 & 648.5 & 901.0 & 1365.1 \\
\hline Zhytomyr & 33.6 & 12.8 & 1033.7 & 1993.3 & 3360.3 \\
\hline Zakarpattia & 51.4 & 12.8 & 657.8 & 777.8 & 1202.0 \\
\hline Ivano-Frankivsk & 41.0 & 13.9 & 588.0 & 843.8 & 1161.5 \\
\hline Kyiv & 22.2 & 28.9 & 592.8 & 1039.3 & 1659.2 \\
\hline Lviv & 28.5 & 21.8 & 629.1 & 1044.7 & 1178.0 \\
\hline Odessa & 6.1 & 33.3 & 199.8 & 73.3 & 89.7 \\
\hline
\end{tabular}




\begin{tabular}{|l|l|l|l|l|l|}
\hline Rivne & 36.4 & 20.1 & 745.9 & 1233.6 & 1671.1 \\
\hline Sumy & 17.8 & 23.8 & 428.1 & 933.0 & 992.3 \\
\hline Chernivtsi & 29.2 & 8.1 & 242.8 & 509.9 & 656.5 \\
\hline Chernihiv & 20.9 & 31.9 & 667.9 & 914.8 & 1564.1 \\
\hline Ukraine & 15.9 & 255.1 & 9665.60 & 13774.6 & 18913.9 \\
\hline
\end{tabular}

Source: State Statistics Service of Ukraine (2018).

Forests have significant economic value, but the most important is environmental. They perform water protection, protective, recreation, sanitary function. Forests have an impact on climate formation; water balance and river runoff; protects soils from erosion processes; acts as a factor of environmental stability and promotes oxygen recovery.( Gryshova, I.; Demchuk, N.; Koshkalda, I.; Stebliuk, N.; Volosova, N.2019)

It should be noted that forest restoration measures of forest lands cover more than $45-50 \%$ of hectares annually, given the considerable volume of forest loss, the domestic use of forest resources does not meet the ecologically balanced requirements today. On the economic side, there is no investment in reforestation and forestry. The theoretical and methodological aspects of the development of the forest sector of the economy and the legal mechanism are considered imperfect.

Table 2. Area of forest reproduction by sowing and planting of forest in the border regions of Ukraine.

\begin{tabular}{|c|c|c|c|c|c|c|c|c|}
\hline \multirow{3}{*}{$\begin{array}{l}\text { Border } \\
\text { regions of } \\
\text { Ukraine }\end{array}$} & \multicolumn{7}{|l|}{ Years } & \multirow{3}{*}{$\begin{array}{l}2017 \\
\text { to } \\
2010 \text {, } \\
\%\end{array}$} \\
\hline & 2005 & 2010 & 2013 & 2014 & 2015 & 2016 & 2017 & \\
\hline & \multicolumn{7}{|c|}{ Total, ha } & \\
\hline Vinnytsia & 1276 & 2791 & 1910 & 1733 & 1963 & 2147 & 2312 & 181.1 \\
\hline Volyn & 3093 & 2400 & 2324 & 1781 & 2108 & 2359 & 2534 & 81.9 \\
\hline Zhytomyr & 5308 & 4282 & 5332 & 5238 & 6416 & 7440 & 7921 & 149.2 \\
\hline Zakarpattia & 1955 & 1122 & 1157 & 1261 & 1361 & 1387 & 1412 & 72.2 \\
\hline $\begin{array}{l}\text { Ivano- } \\
\text { Frankivsk }\end{array}$ & 1699 & 1080 & 1890 & 1631 & 1722 & 1666 & 1734 & 102.1 \\
\hline Kiev & 3437 & 2307 & 2589 & 2458 & 3753 & 3599 & 3823 & 111.2 \\
\hline Lviv & 4138 & 2422 & 2297 & 2268 & 2413 & 2569 & 2654 & 64.1 \\
\hline Odessa & 389 & 3218 & 2117 & 401 & 265 & 221 & 241 & 61.9 \\
\hline Rivne & 2997 & 3505 & 4115 & 4096 & 4249 & 4386 & 5216 & 174.0 \\
\hline Sumy & 1921 & 2214 & 2119 & 1934 & 1935 & 1895 & 1794 & 93.3 \\
\hline Chernivtsi & 1391 & 1103 & 1191 & 1158 & 990 & 820 & 698 & 50.1 \\
\hline Chernihiv & 2894 & 2656 & 3341 & 2963 & 3977 & 3946 & 3849 & 132.9 \\
\hline Ukraine & 45,855 & 56,076 & 48,902 & 38,028 & 40,417 & 42,342 & 42,651 & 93.1 \\
\hline
\end{tabular}

Source: State Statistics Service of Ukraine (2018).

According to statistics, the area of forest reproduction through sowing and planting of forests in Ukraine compared to 2005 decreased by $93.1 \%$ in 2017 year for the border regions, the area of forest reproduction decreased on average by $65.5 \%$ (Table 2). As we can see, reproduction is an integral part of the growth of forest resource potential, because planting forests is of utmost importance.

In terms of forest cover, Ukraine is a little wooded countries in Europe is just (15.9\%). In many countries of the world, this figure is much higher (according to FAO, for example: in Finland the forest cover is 58.9 \%, in Sweden - 67.7 \%, in Germany - 29 \%, in France - 28.7 \%, in Italy - $21.2 \%$, in Canada $26.6 \%$ ) (Fig. 1). 


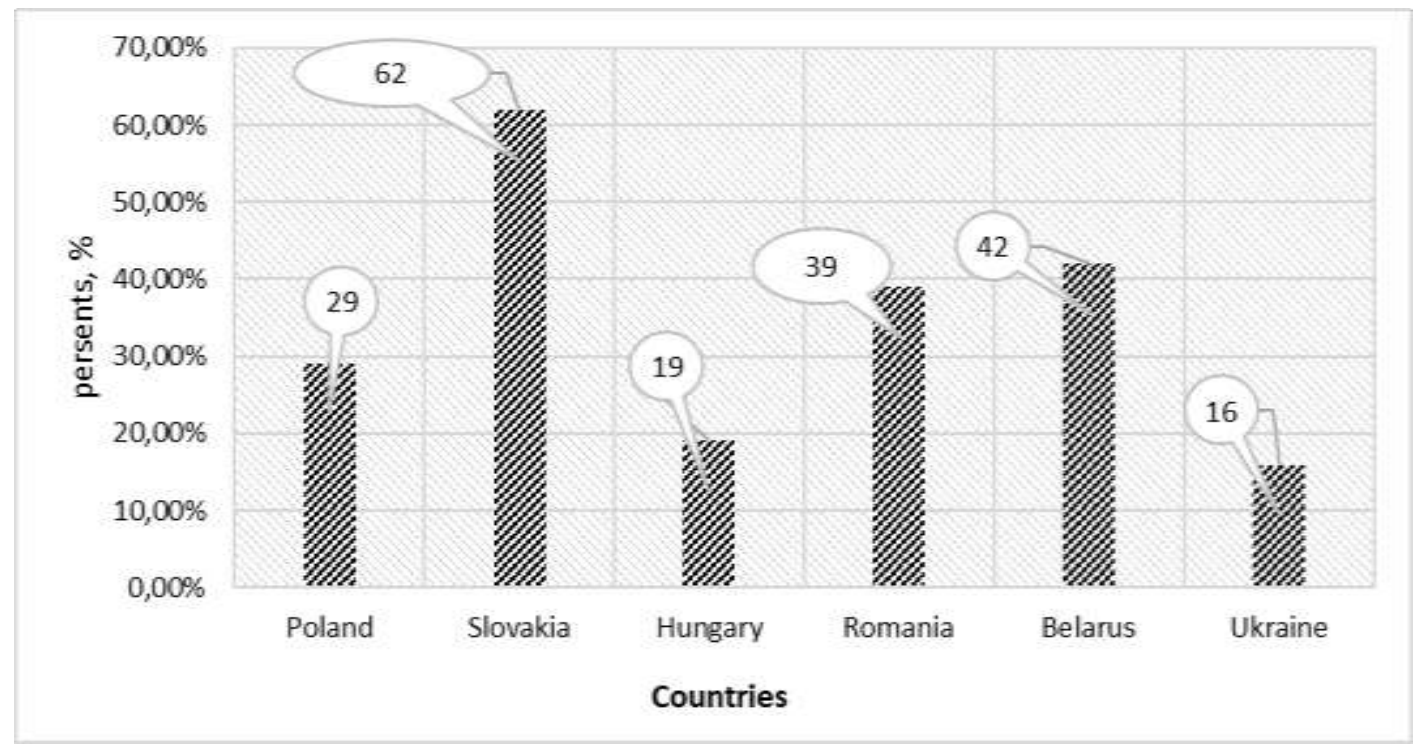

Fig. 1. Forestry of neighboring countries with Ukraine. Source: FAOSTAT 2019.

According to expert estimates, in order to achieve an optimal level of forest cover in Ukraine, which would average $20 \%$, it is necessary to plant forest vegetation of about 2.5-3 million hectares (Stepanenko 2008). It should be noted that such forestry aspects are definitely needed among other countries of cross-border and border co-operation, since Ukraine is the most deficient country (Fig. 2).

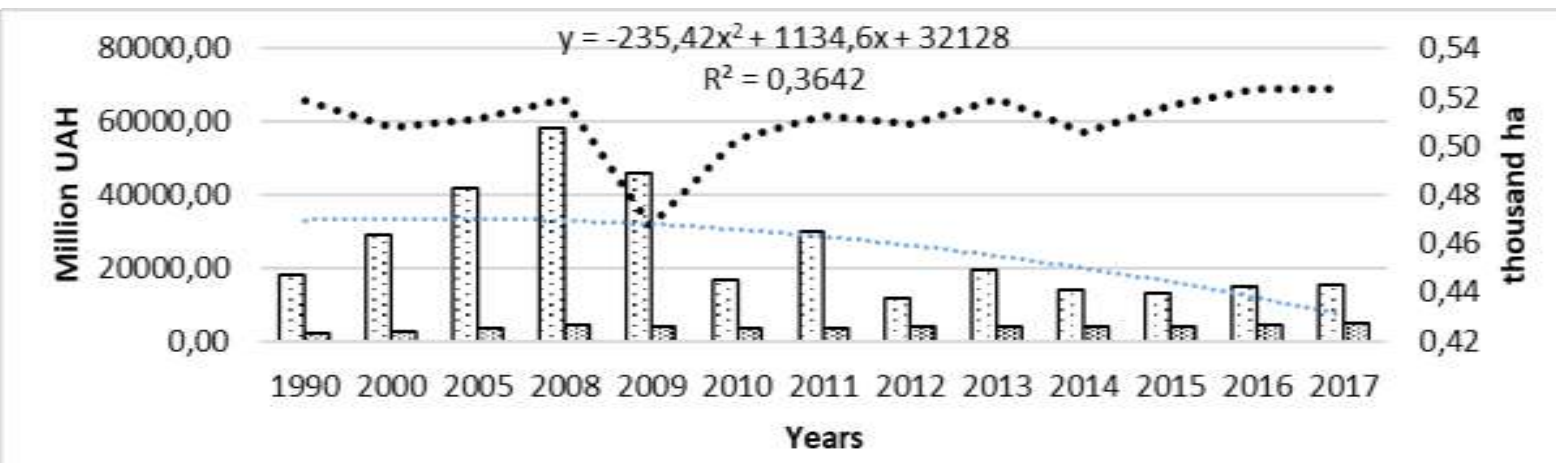

$\ldots$

Capital investment for the rational use of natural resources (million UAH)

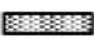

Area of forest reproduction, by region (thousand ha)

...... ecological stability factor

Fig. 2. Relationship between capital investments for the rational use of natural resources, UAH million, area of forest reproduction, by region, thousand ha and the environmental stability factor for the period 1990-2017.

Source: State Statistics Service of Ukraine (2018).

Regarding the structure of capital investments for environmental protection, UAH million, the indicator for this period is reduced. At the present stage, the volume of capital investments and current expenditures for environmental protection in the border area of Ukraine is low, as there is a need to increase investment at the state level, stimulate the flow of foreign investment into the environment in the border regions of Ukraine for development.

Foreign experience demonstrates the high efficiency of investments in environmental programs and cross-border cooperation projects. As wastewater treatment, waste treatment, reforestation can be 
profitable in both transboundary and border areas. Cross-border cooperation in the environmental field leads to the implementation of environmental projects at the international level and creates a favourable atmosphere of mutual relations on both sides of the border, which are exacerbated by the aggravation of global environmental problems at the regional level, as well as the possible transboundary impact of natural and negative environmental effects.

Supporting and stimulating high-level investment activity is an important prerequisite for economic development. It is known that the dynamics of foreign direct investment depends on both the investment attractiveness of the country as a whole and its individual regions. Although FDI volumes are low compared to the investment costs of Ukrainian enterprises, in the long run, given the improved investment climate and sound regional policy, their volume can increase significantly (Vasyltsev 2014)

Effective implementation of increasing the investment attractiveness of the border regions of Ukraine is hindered by a number of factors (Investment attractiveness of Ukrainian regions 2014, Shevchenko 2014), such as:

- Insufficient institutional support for investment policy in the regions and on the ground (investment policy development has traditionally remained the prerogative of central level authorities);

- imperfections of the instruments of opening up the internal potential of the regions through regional strategies (since the existing regional development strategies provide an analysis of specific industries and spheres of activity that form the economic basis for a given region, but there is no systematic and comprehensive analysis of the internal potential of the region and identify ways of using it);

- low efficiency of distribution of investments and low return on investment in the border regions of Ukraine (there is a lack of investment resources in those regions where in the structure of the GRP is dominated by one extractive sector or agriculture; lack of investment does not allow to unlock the internal potential of utilization resources and expand the resource boundaries of investment activities).

- the decline in investment attraction as a result of the worsening socio-economic situation in the country and the decline in the investment attractiveness of the regions of Eastern Ukraine due to hostilities in their territory. It is important to note that in the 'Investment attractiveness rating of regions of 2014' regions of Eastern Ukraine suffered a significant fall in positions: Donetsk region ranked 22nd (3rd place in 2013), Lugansk region - 23rd place (9th place in 2013) (Vasyltsev 2014).

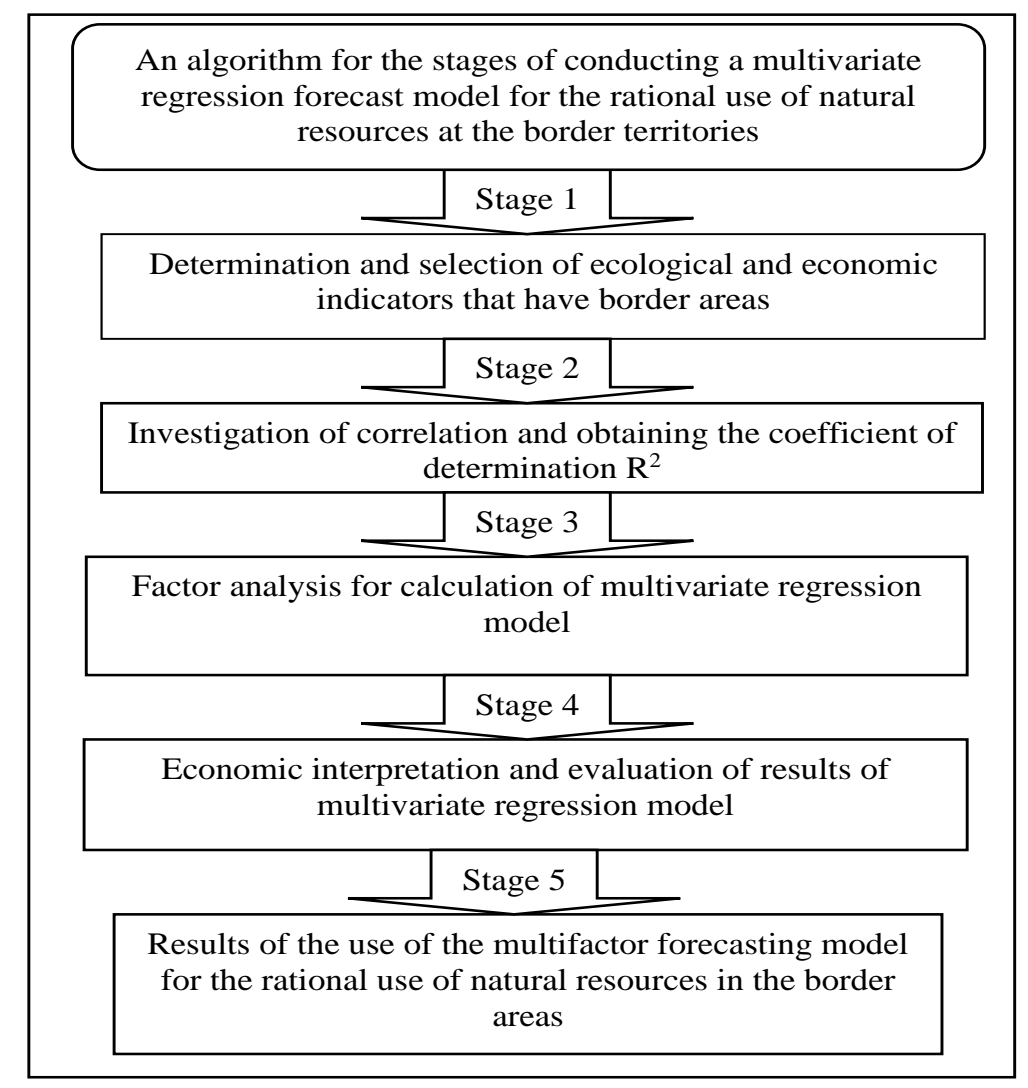

Fig. 3 An algorithm for the steps of conducting a multivariate regression model. 
Taking into account ecological and economic indicators affecting the state of the environment, which should be analyzed in detail in the multifactor forecast model for the rational use of natural resources in the border territories of Ukraine to determine the stepwise correlation-regression relationship (Fig. 3).

To calculate these indicators, a different set of factor values and time intervals have been formed to determine the most significant factors influencing the environmental status of border areas. The ecological and economic model of the border regions of Ukraine has been calculated, which envisages the relationship between the ecological and economic system of the region. The model makes it possible to evaluate the comparative analysis of ecological and economic indicators of the development of the border regions of Ukraine. The research results make it possible to form elements of a multifactor forecast model of the ecological and economic mechanism of natural resources use in the border regions of Ukraine. Areas of forest restoration are analyzed for the use of the ecological and economic mechanism and using the model, trends are estimated and forest reproduction is forecasted. It is shown that investments for the rational use of natural resources, thousand dollars. The US increased in 2017 compared to 2000 (45.3\%), the percentage increase in environmental tax, which is (65.6\%). There is a high level of correlation between the proposed criteria and the effectiveness of forest reproduction, which depends on several factors. First, it depends on the time; wood has the property of natural reproduction in the absence of external factors. Secondly, forest reproduction also depends on investments for the rational use of natural resources, the environmental tax and the gross regional product (GRP). The high level of correlation suggests that the above data can be applied to construct a predictive model by linear multivariate regression, characterizing the ecological and economic parameters - equation (1).

$$
Y=k_{1} * \operatorname{cor}_{1} * f_{1}(T)+k_{2} * \operatorname{cor}_{2} * f_{2}(I)+k_{3} * \operatorname{cor}_{3} * f_{3}(E)+k_{4} * \operatorname{cor}_{4} * f_{4}(V)+k_{5},
$$

where: $Y$ - reforestation, thousand ha; $T$ - time in years; $I$ - investments for the rational use of natural resources, thousand dollars; $E$ - environmental tax, thousand UAH; $V$ - GRP, thousand UAH; cor correlation coefficients; $f_{i}$ - features selected through correlation analysis; $k_{1}-k_{4}$

- model weights; $k_{5}$ - offsetting supplement.

The correlation analysis established the following dependencies between the values and made it possible to conclude the appearance of the main model function.

Table 3. Ranking of criteria.

\begin{tabular}{|l|l|l|}
\hline Criteria & $\begin{array}{l}\text { Biggest } \\
\text { coefficient }\end{array}$ & Rank \\
\hline $\begin{array}{l}\text { Investments in the rational use of } \\
\text { natural resources, thousand dollars } \\
\text { USA }\end{array}$ & Log-0.66 & 5 \\
\hline Environmental tax, thousand UAH. & Log-0.96 & 2 \\
\hline Gross regional product & Log-0.99 & 1 \\
\hline Reforestation, thousand ha. & Lin -0.805 & 4 \\
\hline Environmental tax, thousand UAH. & Log-0.81 & 3 \\
\hline
\end{tabular}

From the obtained data the largest of the coefficients in the correlation analysis implies that shown by equation (2).

$Y=k_{1} * \operatorname{cor}_{1} * T+k_{2} * \operatorname{cor}_{2} * \ln (I)+k_{3} * \operatorname{cor}_{2} * \ln (E)+k_{4} * \operatorname{cor}_{4} * \ln (V)+k_{5}$,

The least squares (OLS) method was used to find the coefficient values $k_{1}-k_{4}$. This method assumes values that minimize the sum of squares of residuals across all observations - by equation (3).

$\hat{k}=\arg \min _{\beta} \sum_{\mathrm{i}=1}^{\mathrm{n}}\left|y_{\mathrm{i}}-\beta_{0}-\sum_{\mathrm{j}=1}^{\mathrm{k}} X_{\mathrm{ij}} \beta_{\mathrm{j}}\right|^{2}$,

where: $\hat{k}$ - vector of parameter values estimates, $\left(k_{1_{s}} k_{2, \ldots} k_{\mathrm{MI}}\right)$, $y_{\mathrm{i}}$ - estimated data, $X_{\mathrm{ij}}$ - input data (Mayboroda 2007).

Based on initial data by the least squares method is calculated weights and compensating summand after substituting into the formula derived equation (4) reception is as presented by equation (4).

$$
Y=237.461 * T+840.382 * \ln (I)-399.929 * \ln (E)-478082 \text {, }
$$

The dependence between environmental and economic factors on regeneration in the border regions of Ukraine. 
The degree of correlation of the index of forest restoration in thousands of hectares by the following indicators was investigated: investments for rational use of natural resources, environmental tax, gross regional product. According to the results of the developed model, it is shown that while maintaining the current trends for forest restoration, investments for the rational use of natural resources gradually decrease, and the environmental tax increases and will amount to UAH 88790 thousand in 2030.

The developed model makes it possible to predict forest restoration, thousand hectares of the border regions by 2030 (Table 4).

Table 4. Model parameters forecast and forest restoration, thousand ha to 2030 years.

\begin{tabular}{|c|c|c|c|c|c|c|c|c|}
\hline \multirow{2}{*}{ Criteria } & \multicolumn{8}{|l|}{ Years } \\
\hline & 2018 & 2019 & 2020 & 2021 & 2022 & 2023 & 2025 & 2030 \\
\hline $\begin{array}{l}\text { Investments in } \\
\text { the rational use } \\
\text { of natural } \\
\text { resources, } \\
\text { thousand } \\
\text { dollars USA }\end{array}$ & 12440 & 10577 & 8716 & 6856 & 4996 & 3137 & 1280 & 1340 \\
\hline $\begin{array}{l}\text { Environmental } \\
\text { tax, thousand } \\
\text { UAH. }\end{array}$ & 58685 & 62429 & 66172 & 69913 & 73652 & 77388 & 81124 & 88790 \\
\hline $\begin{array}{l}\text { Gross regional } \\
\text { product, } \\
\text { thousand UAH }\end{array}$ & 60965 & 64759,1 & 68551,3 & 72341,6 & 76130 & 79916,6 & 83701,3 & 89451,8 \\
\hline $\begin{array}{l}\text { Reforestation, } \\
\text { thousand ha }\end{array}$ & 4290 & 4287 & 4260 & 4197 & 4078 & 3851 & 3315 & 3187 \\
\hline
\end{tabular}

Based on the correlation analysis, it was proved that there is a sufficient level of influence on the volume of foreign investments on the environmental tax, the costs of enterprises for the protection and rational use of natural resources, the volume of emissions per person indicates a moderate direct relationship between these environmental and economic factors. In general, the study of the main positive and negative factors of the investment attractiveness of the border regions of Ukraine revealed: good geographical location of the border regions, temperate climate - these are the basic positive factors, as well as the elimination of a number of shortcomings, such as imperfect legal framework, high inflation and low inflation rates. on the development of the border areas of Ukraine. The investment mechanism of rational environmental management should be considered as: economic phenomenon, which reflects the current state of attractiveness of environmental objects in the investment and development of the latest technologies of investment or innovation activity from different sources of investment and their origin at different levels of management.

But it is worth paying attention to the project of developing a program of financial and investment support for the border regions of Ukraine. The priorities of this integrated nature management program correlate with the basic provisions of international agreements that create positive institutional support for attracting foreign investment, and should also pay attention to attracting investment support at the regional level in the border areas of Ukraine. 


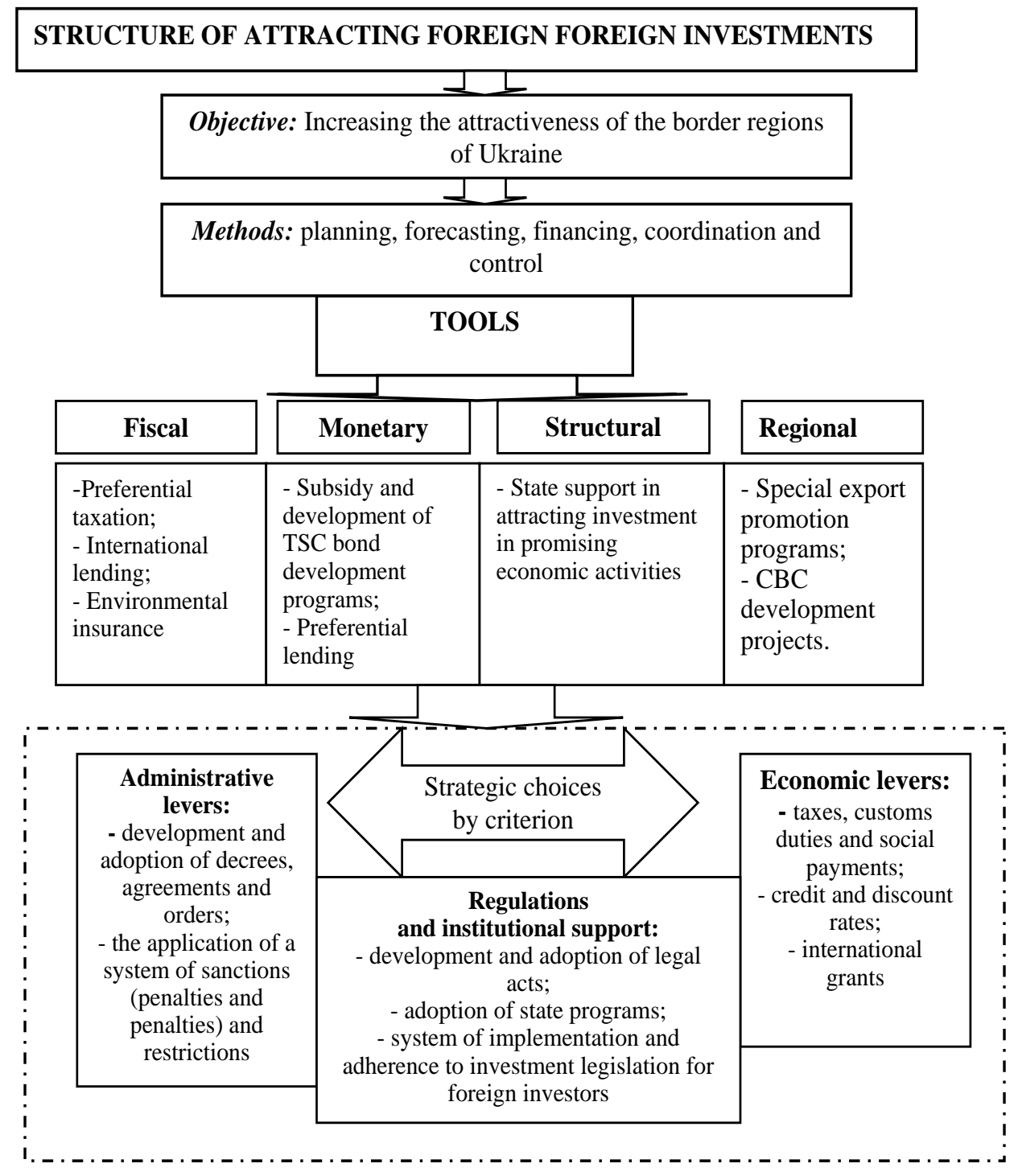

Fig. 4. Structural and conceptual scheme of attracting investments in the development of border areas Ukraine on the use of natural resources.

The simplest form of attracting foreign capital is joint ventures, which in the form of a commercial organization are overwhelmingly joint stock companies. In the current wording of the law (Law of Ukraine 2003). Investment is a major driver of eco-economic growth. They provide structural restructuring of the economy in the border areas, because the transition to a new innovative level of development, solving employment problems, development of the social sphere, so the most important task for the border regions is the formation of levers to intensify investment processes at the regional level. The strategic purpose of the formation of mechanisms is to attract investment resources for environmental protection. Tasks formed on the basis of the objectives of the mechanism are to maintain favorable region proportions in the sources of investment funds, investment directions and types of values. The criteria of the mechanism are intended to ensure the implementation of the strategic and tactical goals of levers, incentives used by regional authorities and local self-government bodies within their powers, with the aim of forcing in this territory the conditions for expanded reproduction and ensuring ecological and economic development. Investments in environmental direction can now be deducted from environmental payments, insurance compensation, which may be in environmental funds, as such funds must be created at the polluting enterprises (Fig. 4).

\section{Conclusions}


The gradual transition to market conditions of nature management, forest resources of Ukraine still remain the property of the state, while the means of their use in production processes have become privately owned. Therefore, it is necessary to develop a toolkit of combining forest resources and their means of cultivation in a single production and economic cycles, which in modern conditions can be implemented through an investment-project approach, within which it is possible to achieve the goal of resource owners and owners of means of production, as well as to balance the interests of all participants and ensure the rational and profitable use of forest resources.

Currently, the development of border regions and cross-border cooperation is under development, with considerable emphasis on environmental management. This is because of divergences in strategies for the development, protection, management and reproduction of natural resources, and the conservation of the environment in environmental law. After all, cross-border cooperation opens up new opportunities for economic integration. Today, the development of international relations has helped to find new leadership directions for cross-border cooperation on both sides of the border. Ukraine's development is impossible without participation in European processes that are important for attracting foreign investments and new technologies, creating new jobs, entering new world markets and ensuring economic, environmental and social processes.

\section{References}

Andel I.V. 2009. Ekonomichnyj, finansovyj ta ekologichnyj aspekty investycijnoi' pryvablyvosti regionu [Economic, financial and environmental aspects of the region's investment attractiveness]. Scientific Bulletin of NLTU of Ukraine. Vol. 19.10: 126-141. (in Ukrainian).

Antonenko I. 2001. Ekoloho-ekonomichna otsinka efektyvnosti vykorystannya i okhorony lisovykh resursiv [Ecological and economic evaluation of the efficiency of use and protection of forest resources]: dis. ... The candidate of economics. Sciences: 08.08.01, Kyiv, 2001. 190 p. (in Ukrainian).

Drebot 0. 2012. Systema instytutsionalnoho zabezpechennya pryrodokorystuvannya v lisovomu sektori ekonomiky [System of institutional support of nature management in the forest sector of economy]. Balanced nature management 1: 25-29 (in Ukrainian).

Gryshova, I.; Kyzym, M.; Khaustova, V.; Korneev, V.; Kramarev, H. 2020 Assessment of the Industrial Structure and its Influence on Sustainable Economic Development and Quality of Life of the Population of Different World Countries. Sustainability 12(5), 2072. P. 17-18.

FAOSTAT 2019. Forest product statistics. Available at: http://www.fao.org/forestry/statistics/en/

Furdychko O. Drebot O., Bobko A. 2017. Lis i lisovi ekosystemy u skladi zemel' lisohospodars'koho pryznachennya [Forest and forest ecosystems in the composition of forest lands]. Bulletin of agrarian science 10: 56-60 (in Ukrainian).

Furdychko O., Shershun M., Shkuratov O., Drebot O., Yaremko 0. 2019. Assessment of the efficiency of sustainable forest management in Ukraine. Forestry ideas, vol. 25, No 2(58): 339-350.

Investment attractiveness of Ukrainian regions 2014. Institute for Economic Research and Policy Consulting. State Agency for Investments and Management of National Projects of Ukraine [Electronic resource]. (in Ukrainian). Available ht: htt//www. http://www.ier.com.ua/files/Projects/2012/\%D0\%A0\%2014.pdf

Law of Ukraine 2003. Law of Ukraine of 24.12.2002 No 349-IV. On taxation of profits of enterprises: Government courier. 2003. No 12: 2-12 (in Ukrainian).

Mayboroda R. 2007. Rehresiya: liniyni modeli [Regression: linear models]. Kyiv: University. 296 p (in Ukrainian).

Shershun M. 2013. Napryamy reformuvannya orhanizatsiyno-ekonomichnoyi struktury upravlinnya lisovym hospodarstvom [Directions for reforming the organizational and economic structure of forestry management]. Balanced nature management 1: 5-12 (in Ukrainian).

State Statistics Service of Ukraine 2018. 'Statystychnyy shchorichnyk Ukrayiny za 2017 rik. Statystychnyj zbirnyk' [Statistical Yearbook of Ukraine for 2018. Statistical yearbook], Derzhkomstat, Kyiv (in Ukrainian).

Wadim Strielkowski, Gryshova I.Yu (2018) Academic publishing and «predatory» journal. Nauka innov., 14 (1) C.5-12

Gryshova, I.; Shabatura, T.; Girdzijauskas, S.; Streimikiene, D.; Ciegis, R.; Griesiene, I. The Paradox of Value and Economic Bubbles: New Insights for Sustainable Economic Development. Sustainability 2019, 11, 6888.

Gryshova, I.; Demchuk, N.; Koshkalda, I.; Stebliuk, N.; Volosova, N. Strategic Imperatives of Managing the Sustainable Innovative Development of the Market of Educational Services in the Higher Education System. Sustainability 2019, 11, 7253. 
Wadim Strielkowski, Evgeny Lisin, Inna Gryshova.(2016) Climate Policy of the European Union: What to Expect from the Paris Agreement? Romanian Journal of European Affairs Vol. 16, No. 4, December 2016 Dr. Tetiana Tielkiniena, Gryshova Inna, Shabatura Tatyana, Nehodenko Viktoriia, Didur Hanna, Shevchenko Alisa. LOBBY LEGALIZATION - LEGAL INSTRUMENT FOR ENSURING STATE SUBSIDIES TO LEADERS OF AGRICULTURAL PRODUCERS . JCR. 2020; 7(4): 1679-1683. doi:10.31838/jcr.07.04.274

Azer Dilanchiev, Gryshova Inna, Rogach Svetlana, Diachenko Oleksii, Batrakova Tetyana, Shabatura Tatyana. REMITTANCE LEVELS AND ENTREPRENEURIAL ACTIVITY IN POSTSOVIET COUNTRIES . JCR. 2020; 7(4): 1655-1663. doi:10.31838/jer.07.04.271 